https://www.sworldjournal.com/index.php/swj/article/view/swj09-02-001

DOI: 10.30888/2663-5712.2021-09-02-001

\title{
THE POLYTHEISTIC PSYCHE: RE-IMAGINING SOUL AND SELF IN JAME'S HILLMAN'S ARCHETYPAL PSYCHOLOGY
}

\author{
King J.R \\ PhD Candidate, Faculty of Philosophy, \\ University of Salamanca, Spain
}

\begin{abstract}
This article examines the notion of psychological polytheism in the context of Jungian depth psychology. The author focuses on the concept of the "polytheistic psyche" which American psychologist and philosopher James Hillman, founder of the post-Jungian branch of Archetypal Psychology, has put forth as part of a broader re-imagining of the field. Theorizing against a backdrop of mythological metaphor, Hillman maintains that the psyche is by nature plural, and the human personality is ultimately multiple, not unitary. Psychological wholeness of Self means the health of diverse points of view and multiple relations within the psyche, not wholeness in the traditional theological sense meaning a unity of "the one."

Key words: archetypal psychology, imaginal psychology, psychotherapy, C.G. Jung, postJungians, James Hillman, imagination, religion, theology, polytheism, soul, psyche, soul-making.
\end{abstract}

\section{Introduction.}

Regarded as one of the most innovative heirs to the depth psychology tradition inaugurated by C.G. Jung, the American psychologist and philosopher James Hillman (1926-2011) is the founder and sustaining voice of Archetypal Psychology, a postJungian psychology which emphasizes a movement beyond the context of clinical analysis towards a "psychology of soul" situated within the culture of imagination, metaphor, and Western mythology. In Archetypal Psychology we encounter the following principal themes or main ideas: (1) a shifting of focus away from the rational ego and towards the soul; (2) an emphasis on image and imagination as soul's natural language and activity; (3) the exploration of a background of mythological metaphor which offers a vision of the soul as plural and polytheistic; (4) and the elaboration of a process of "soul-making"- an imaginative, aesthetic response to life that seeks to enrich the relationship between man, soul, and the world.

As part of his program to elaborate an aesthetic psychology of soul, Hillman has asked what idea today governs our image of the psyche, "the many or the one?" $[2$, 110]. His answer is that the West has made a norm out of the singleness of soul, where unity and integration are held to be desirable advances over multiplicity and diversity, where "health of wholeness" has meant "the one dominating the many" [2, 114-116]. Consistent with his belief that religion, or theology, influences psychology, Hillman maintains that this is but only one consequence of a deleterious legacy that monotheistic religion (particularly fundamentalist Christianity, which has regarded the image literally rather than metaphorically) has inflicted upon psychology as well as the wider cultural imagination [5]. This inheritance has so conditioned our image of soul, says Hillman, that we remain "ruled by a bias toward the one" $[2,110]$.

However, instead of making a singleness out of soul, Archetypal Psychology portrays the soul as "inherently multiple." Affirming this conception of the psyche, Thomas Moore has noted that an authentic psychology conceived from the point of view of soul and the imagination necessarily "gives place to multiplicity, not demanding integration and other forms of unity, and at the same time offer[s] a 
language adequate to a psyche that has many faces" $[9,37]$. Yet, in describing the nature of psyche as multiple, Hillman doesn't choose a word like "multifaceted" to characterize these many faces. Instead, he appropriates from religion and mythology a more animated word, polytheism, implying an essential and profound plurality in the soul $[9,37]$. With the term polytheism, Hillman advocates a polytheistic rather than a monotheistic psychology, and he seeks to return to, or better yet retrieve and bring forward polytheistic mythology as a fertile metaphoric background for imagining the psyche in its inherent multiplicity.

\section{Main Text.}

The notion of polytheism was first employed in the context of psychology by Jung as a means of characterizing the "objective psyche," which he believed to consist of a multiplicity of partial personalities [2]. Jung had already described the psyche as polycentric and pluralistic based on his studies of the alchemical idea of the lumen naturae, or the light of nature, which the Swiss alchemist Paracelsus had equated to the anima mundi. Traditional descriptions of the anima mundi or soul-ofthe-world maintained that the light of nature was multiple, and when Jung in his turn directed his psychological eye toward the lumen naturae, he wrote of it as multiplicity of partial consciousnesses, like stars or divine sparks- "luminosities." With its polytheistic perspective, archetypal psychology's understanding of the psyche "corresponds with this description [of multiplicity] and provides its imagistic formulation in the major traditional language of our civilization", i.e., classical mythology $[2,114-116]$. The mythological gods are, then, the images through which the western psyche was once manifested in ancient Greece.

Hillman finds in the mythological polytheism of ancient Greece an effective paradigm for envisioning the psyche as not only multiple, but as "a communion of many persons each with their specific needs, fears, longings, styles and language" [9, 37]. This collective of persons echoes the many points of view that underlie what appears to be a unified human being. The persons of dreams, for example, represent the many personalities who play a role in the everyday dramas of the psyche. As a polytheistic psychology, Hillman maintains that a central task of his imaginal method is to reinvigorate this relationship with the multiple figures of psyche as beings in their own right, beings that demand to be approached according to their own principles, allowing each voice to be heard. A polycentric approach accepts a multiplicity of voices without insisting on unifying them into one figure. Wholeness, then, comes to mean the health of multiple relations within the psyche, not wholeness in the traditional theological sense which means a unity of the one. A focus on diversity leads to deeper insights into psychic images and their relationships to one another.

In keeping with Hillman's use of the designation "archetypal" to refer to a perspective that sees through the literal into its metaphorical background, as well as to a move one makes which places whatever is seen in a mythic perspective, Hillman has emphasized that archetypal psychology is neither a religion nor a theology. These gods and goddesses are "neither believed in nor addressed directly, as they are adjectival rather than substantive" [4, 129]. He says that it is only when these qualities "are literalized, set apart as substances, that is, become theologized, do we 
have to imagine them through the category of belief" [ibid.]. In this respect, Archetypal Psychology does not worship the gods. Psychological polytheism is not about worship, but about an attitude, a way of looking at things, and the perspective we bring to life. The myths in which the gods enact their dramas are themselves understood "as metaphors, never as transcendental metaphysics whose categories are divine figures" $[4,114]$. Hillman emphasizes that all statements concerning myths and the gods are to be taken metaphorically, "pre-fixed with an 'as-if,' just as all speaking about the archetypal presences of the psyche "are translations from one metaphor to another" [3, xiii]. When we keep this perspective in mind, we enable ourselves to engage the nature of soul in an imaginative way and approach the basic questions concerning psychology first of all by means of the imagination.

The variety of perspectives portrayed in these mythical paradigms proves to be always more psychological, that is, psyche-logical, than "scientific" psychology's volumes of literalized concepts and lifeless ideas. Myths, he says, "produce more insights into emotions, images and relationships and reflect more accurately the illusions and entanglements of the soul" [4, 114-116]. Mythical paradigms provide a variety of perspectives and styles of thought that offer the possibility of metaphoric insight into the events of our lives and the prospect of differentiating the particularities of psychic phenomena. Hillman offers the example of the experience of depression, which from this mythic point of view might be understood on the model of Christ and his suffering and resurrection; it may through Saturn gain the depth of melancholy and inspiration, or through Apollo serve to release the black bird of prophetic insight. From the perspective of Demeter depression may yield awareness of the mother-daughter mystery, or through Dionysus, we may find depression a refuge from the excessive demands of the ruling will $[4,114]$.

Focusing upon the many and the different, rather than upon the one and the same, provides multiple modes of looking at and of discovering the virtues in our psychic conditions. Once understood metaphorically, we begin to experience these archetypal gods as living figures within our personalities, "personifications of psychic forces" [7, 10, par. 185]. Myths become the "backgrounds to the complexity of human nature" $[4,114]$ and mythic consciousness helps us begin to understand the variety of our own psychological dynamics and experience.

When we honor psychic multiplicity, we honor the diversity and ambiguity of our own self-definition. In this context, imaginal psychology maintains that the personality is fundamentally multiple, rather than unitary. This is to suggest quite radically that maybe we don't "have" a personality, that there is no personality, "but rather only personifications which, treated as real persons, assume the status of autonomous personalities" $[4,114]$. Proposing the relativity of all personifications, however, is not to be mistaken with promoting "multiple personality disorder," although Hillman does, in fact, make the bold claim that multiple personality "is humanity in its natural condition" $[6,40]$. However, from the psychological perspective, these many persons or personifications echo all those points of view that underlie what appears to be a unified human being [9, 37]. The persons of a dream, the figures in our imagination and fantasy, for example, represent the many personalities who have a role to play in the psyche's everyday dramas. 
Archetypal Psychology's polycentric approach therefore seeks to use the imagination in order explore the relations between all personifications and dream figures. It does so by observing, listening, and attending carefully to each particular image of their presentation, making sure to allow each one their due- even those figures of the imagination that the predominant ego point of view might find abhorrent or threatening to its position of authority. It is in this light also that Hillman encourages us to remember that even the "I" of the ego is only one point of view, one figure, one image, among the multiple figures of the psyche. Viewed in this manner, says psychologist Michael Vannoy Adams, to regard the multiplicity of personality as a psychiatric "aberration" is simply "evidence of a cultural prejudice that erroneously identifies one partial personality, the ego, with the personality as such" $[1,115]$. As professor of religion David Miller has articulated, polytheism and a polytheistic view of the psyche allows a person to experience himself or herself as many different and yet coextensive selves, each of which is felt to have autonomous power [8].

With respect to the age-old philosophical problem of "the one-and-the-many", it is evident that Archetypal Psychology values multiplicity over unity. It is Hillman's colleague Rafael López-Pedraza whose own comment most succinctly summarizes this position. Instead of the usual formulation which proposes that unity contains multiplicity, López-Pedraza reverses the formulation and says that "the many contains the unity of the one without losing the possibilities of the many" (LópezPedraza in $[1,115]$. When we imagine and idea of the totality of the soul, Hillman says, "the 'one' appears only as this or that image... and it appears as the unity of each particular event, discoverable phenomenally only within eachness...[U]nity too can be imagined polytheistically" $[2,131]$. This program of cultivating polytheistic consciousness offers a rich alternative to the monotheistic need for unity and integration. The archetypal point of view holds that, "the one does not appear as such but is contained as one among many within each of the many" [ibid].

The polytheistic or polycentric approach of Archetypal Psychology seeks to loosen the grip of what Hillman calls "our true religion," a "monotheism of consciousness," and bring with it the health of a psychological polytheism that recognizes the location of human consciousness "in multiple figures and centers" [3, 26]. In this imaginative orientation of psychology, the multiple perspectives and persons of the psyche are personified against a mythic, metaphoric background, obliging our normally hegemonic ego-consciousness to circulate among a field of powers. The notion of a polytheistic or polycentric psyche means that soul has many sources of meaning, direction, and value. As Moore notes, the richly textured images of polytheistic mythology are themselves therapeutic because they give place to the soul's beauty, variety, and conflict- teaching us at the same time to find vitality in tension, gather wisdom from ambivalence, and learn from paradox $[9,38]$.

Although Hillman finds in mythology an effective paradigm for his psychology, his almost exclusive focus on the Greek gods and goddesses would seem to ignore the ethnic and cultural diversity of the entire global pantheon. However, as Adams has noted, Hillman justifies, or rationalizes, this election on the basis that the field of depth psychology is historically European in origin and that Greek mythology and its gods and goddesses are uniquely influential in that particular cultural context $[1$, 
116]. In sum, this insistence on the mythical polytheistic perspective is reflective of Hillman's belief that our psychic complexity "requires all the Gods", and so he has sought to defend the polytheistic diversity of the psyche from being collapsed into a monotheistic doctrine.

\section{References:}

1. Adams, M. V. (2008). The Archetypal School. In: Young-Eisendrath, P. Dawson, T. (org.): The Cambridge Companion to Jung, Cambridge: Cambridge University Press.

2. Hillman, J. (1971). Psychology Monotheistic or Polytheistic. Spring, 31, pp. 193-207. Row.

3. Hillman, J. (1975a). Re-visioning psychology. New York, NY: Harper and

4. Hillman, J. (1981). "Psychology: Monotheistic or Polytheistic." In D.L. Miller, The New Polytheism: Rebirth of the Gods and Goddesses [1971]. Dallas, Texas: Spring Publications, Inc. pp. 109-142.

5. Hillman, J. (1983a). Healing Fiction. Putnam, CT: Spring Publications.

6. Hillman, J. (2013). Archetypal Psychology. Uniform Edition of the Writings of James Hillman, Volume 1. Thompson, CT: Spring Publication, Inc.

7. Jung, C. G. (1979). Collected Works of Carl Gustav Jung (R. F. C. Hull, Trans.). Princeton, NJ: Princeton University Press.

8. Miller, D. L. (1981). The New Polytheism: Rebirth of the Gods and Goddesses. Dallas, Tex.: Spring Publications.

9. Moore, T. (Ed.). (1989). Blue Fire: Selected Writings by James Hillman. New York, NY: Harper Perennial. 